Paideusis

\title{
Free Children and Democratic Schools: A Philosophical Study of Liberty and Education (Rosemary Chamberlin)
}

John P. Portelli

Volume 6, Number 1, 1992

URI: https://id.erudit.org/iderudit/1073345ar

DOI: https://doi.org/10.7202/1073345ar

See table of contents

Publisher(s)

Canadian Philosophy of Education Society

ISSN

0838-4517 (print)

1916-0348 (digital)

Explore this journal

Cite this review

Portelli, J. (1992). Review of [Free Children and Democratic Schools: A Philosophical Study of Liberty and Education (Rosemary Chamberlin)]. Paideusis, 6(1), 39-42. https://doi.org/10.7202/1073345ar 


\title{
Book Reviews
}

Rosemary Chamberlin, Free Children and Democratic Schooks: A Philosophical Study of Liberty and Education (New York: The Falmer Press, 1989)

\section{The short description on the bookcover states that}

\begin{abstract}
Free Children and Democratic Schools relates a theory of liberty to the practice of education, and reveals the implications of beliefs about freedom for our schools and classrooms. The author makes a reasoned plea for society to have more respect for children and not treat them as an inferior sub-species. The central argument of the book is for greater education in democracy, and greater democracy in education.
\end{abstract}

While bearing in mind that this book is essentially a general introduction to the topic, it does not totally fulfil these expectations. While the author provides a "theory of liberty," offers a defence of it, and shows some important implications that follow from it about the practice of education, the "plea" provided by Chamberlin for more respect for children is too moderate and, unfortunately, lacks the enthusiasm and support needed to convince and counterbalance a staunch conservative outlook on education and the nature of children. In a nutshell, Chamberlin's call for "greater education in democracy" will not necessarily be understood as, or translate into, "greater democracy in education." To be fair, she does argue for more democracy in education and for more respect for children's views in education, but, her overall position about these matters is, at times, too general and vague, and, on other occasions, rather limited. While I agree with her plea, her position is too mildly stated to have any real impact on the struggle to enhance the possibilities of seriously realizing democracy in schools. Of course, this evaluation is based on the assumption that the role of philosophy of education, especially when dealing with matters of direct political and moral import (such as the ones dealt with in this book), is both to understand and, when necessary, change education.

Before focusing on some more specific points, a quick overview of the book will be offered. The book consists of ten chapters which may be grouped into two parts. The first provides an examination of 'freedom' (chapter 1), develops a theory of liberty by considering the questions about limitations on freedom in a democracy and the right to liberty (chapters 2, 3 and 4), and focuses on the issue of children's rights (chapter 5) which eventually leads to a discussion of paternalism (chapters 6 and 7). It is really in the second part that Chamberlin's thesis about educational matters emerges, for in the remaining chapters she considers "the sort of education we would give our children if we lived up to our own rhetoric about freedom and democracy" (p. 82). In chapter 8 , through a brief exposition and critique of a mixture of views about compulsory education (e.g., Peter Gardner, John White, Paul Goodman, John Kleinig, and Everett Reimer), Chamberlin concludes that education and compulsion are not incompatible, compulsory education being justifiable in principle since "there are certain things they [children] need to know in order to survive in our society, to become part of the community and play their part in it, and to be able to make reasoned choices as individuals" (p. 107). However, she insists that 
this position neither (a) gives a free hand to adults to "impose their own wishes on children" (p. 105) nor (b) "justif[ies] the unlimited restrictions of children's freedom" (p. 105). In chapter 9, she considers the limits of children's freedom in schools with regard to the academic, and social, and personal aspects, in chapter 10 she touches on the possibility of children's participation in the "organization of the school" and "the formulation of school rules."

A major discussion that runs through the book deals with the justification of the limits of children's freedom to act according to their interests, needs, and wants (three things that are not necessarily identical). Her general position that there have to be limits is hard to refute; inevitably, on moral grounds, adults do bave to intervene. She also finely argues that paternalistic activities towards adults and children are not qualitatively different, and she challenges the view (held, for example, by Geoffrey Scarre) that "children are inexperienced in the ways of the world and are incapable of following life-plans or systematic purposes. .." (p. 78). My disagreement arises largely when she applies her position to education. Here she is unnecessarily restrictive or vague. And this does not augur well for her plea concerning more respect for children and greater democracy in education especially with regard to academic matters. I will focus on some points to illustrate my disagreement further.

(i) While she admits that a society which is more democratic than ours would involve more discussion and participation in educational matters, and while she also identifies the importance of people being "socialized or educated to participate" (p. 122) in order to increase discussion and participation, the tone of the quality of her academic educational programme does not seem to encourage the kind of discussion and participation needed in classes and about academic matters. She seems to be too concerned about covering a predetermined, required curriculum to ensure that students get the knowledge, skills, principles, facts, and standards of rationality which, according to Chamberlin, are needed to be able to function in a democracy. This point (or variations of it) is made at least seven times (see pages $51,57,101,102,106,114$, and 123). What is the message one expected to get?

(ii) Chamberlin concludes that ". . .children should not be given complete academic freedom, but should have as much as possible without neglecting what we have deemed they should know. .." (p. 113). But, what is the "what" deemed necessary? Who is the "we"? What process will be used to determine the "what"? And on what criteria? What educational ideal will direct such decisions? What approach to teaching will be pursued in teaching the necessary content? There is no systematic attempt to answer these questions. The most explicit and least vague reply we get is the following: "the 'we' refers to the whole community and not just to teachers, school governors, or the DES" (p. 120). But now, of course, the issue becomes more complicated: what and whose knowledge is considered most worthwhile? (This is meant to be both an epistemological and a political question). And in whose interest will decisions be made?

(iii) Chamberlin holds that "it is the duty of adults to ensure they learn what is worthwhile and what they will need to know rather than what they chance upon or what it is someone else's interest they should learn" (p. 101). Chamberlin, unfortunately, does not flesh out what is worthwhile and what criteria she defends in justifying worthwhile activities. However, she holds that 
students' interests are not to be considered as a major criterion (and perhaps not at all) in determining what is worthwhile. Given her support for participatory democracy, one would have expected her to take the notion of interest more seriously. On the contrary, she simply states that she "question(s) the belief that interest and need will coincide so conveniently" (p. 101). She only considers interests as a factor in increasing children's motivation to faithfully follow a curriculum determined primarily by adults who know best. Her conclusion about students' interests seems to be based primarily on her critique of educationists such as A.S. Neill and J. Holt. This, however, almost trivializes the centrality of interests as a criterion. One needs to emphasize that interests are not identical to any want or desire. Moreover, taking students' interests seriously does not necessarily entail that one holds that "people are . . like acorns which need only sun and water and space to grow into fine oaks"' (p. 101), nor does it mean that children will be left alone. ${ }^{1}$ About the social and personal aspect (e.g., dress code and school regulations), Chamberlin concludes, "if children are respected as people with important ideas of their own, then what they say on the subject of restriction and freedom in school must be listened to" (p. 117).

This is quite a contrast to her conclusion concerning their contribution to academic matters (such as, what subjects to study, criteria for evaluation, directing their own learning). If Chamberlin had considered the work, for example, of Gareth Matthews, Margaret Donaldson, Stephen Rowland, P. Gray and D. Chanoff, and Kieran Egan, then, perhaps her view of children's contribution to academic matters would have been more positive. ${ }^{2}$

(iv) Chamberlin makes three direct references to Dewey's work. One reference (p. 113) deals with Dewey's view on preparation for the future. The other two quotations, also from Experience and Education, are given in support of her view about adult direction and intervention in academic matters. All of these quotations are appropriate. Egan reminds us that "Dewey's writings are notoriously hospitable to quite divergent interpretations, so the selection of particular quotations cannot capture the complexity of his vision." 3 However, it is quite unfortunate that Chamberlin does not refer to Dewey's warning that

It is possible of course to abuse the office, and to force the activity of the young into channels which express the teacher's purpose rather than that of the pupils. But the way to avoid this danger is not for the adult to withdraw entirely. The way is, first, for the teacher to be intelligently aware of the capacities, needs, and past experiences of those under instruction, and, secondly, to allow the suggestion made to develop into a plan and project by means of the further suggestions contributed and organized into a whole by the members of the group. The plan, in other words is a cooperative enterprise, not a dictation. ${ }^{4}$

It is exactly Dewey's vision of democracy as a way of life based on a cooperative enterprise which is missing in Chamberlin's discussion of the curriculum.

Although I have been critical of parts of Chamberlin's position, her book invites us to seriously consider educational matters in a democracy-definitely a very timely consideration given that, as I review this book, the media once again reminds us of yet more cutbacks for schools, governments not honouring teachers' (as well as other government employees') collective agreements, and rumours of the proposal of a national curriculum for Canada. 
There is one other positive note worth mentioning in conclusion. Not many school teachers find the time and have the dedication required to teach and engage in serious philosophical discussions related to their practice. Dr. Rosemary Chamberlin, who teaches in an infant school in Bristol, England, has done so-in this sense, she sets a fine example of the vision of "teachers as intellectuals."

John P. Portelli

\section{Notes}

${ }^{1}$ After all even A.S. Neill and P.S. Wilson, two ardent defenders of students' interests, admit that at times children have to be restricted in their actions. And Paulo Freire, usually labelled "a radical educator" holds:

In some situations, in some circumstances, the democratic goal of liberating education can lead to irresponsibility if the students perceive it as expecting less from them. The responsible educator has ... to (make) an open atmosphere in a number of ways, but never, I repeat, never an atmosphere of laissez-faire, laissez-allez, never, but a democratic atmosphere yes. . .The educator continues to be different from the students, but, and now for me this is the central question, the difference between them, if the teacher is democratic, if his or her political dream is a liberating one, is that he or she cannot permit the necessary difference between the teacher and the students to become 'antagonistic'. The difference continues to exist! I am different from the students! But I cannot allow this to be antagonistic if $I$ am democratic. If they become antagonistic, it is because I became authoritarian. A Pedagogy for Liberation: Dialogues on Transforming Education (South Hadley, Mass.: Bergin and Garvey, 1987), 89-90 and 92-93.

${ }^{2}$ See, G. Matthews, Philosophy and the Young Child (Cambridge, Mass.: Harvard University Press, 1980), and Dialogues with Children (Cambridge, Mass.: Harvard University Press, 1984); M. Donaldson, Children's Minds (London: Fontana, 1978); S. Rowland, "Classroom Enquiry: An Approach to Understanding Children," in D. Hustler, T. Cassidy and T. Cuff (eds.), Action Research in Classrooms and Schools (London: Allen \& Unwin, 1986), 25-35; P. Gray and D. Chanoff, "Democratic Schooling: What Happens to Young Children Who Have Charge of Their Own Education?" American Journal of Education, 94(2), 1986; 182-213; and K. Egan, "Education and the Mental Life of Young Children," Australian Journal of Education, 35(1), 1991, 60-74.

${ }^{3} \mathrm{~K}$. Egan, "Education and the Mental Life of Young Children," 63.

${ }^{4} \mathrm{~J}$. Dewey, Experience and Education (New York: Macmillan, 1938), 71-72. 